\title{
ОЦЕНКА ВЛИЯНИЯ ФАКТОРОВ \\ НА ФИНАНСОВЫЕ РЕЗУЛЬТАТЫ ДЕЯТЕЛЬНОСТИ \\ ПРОМЫШЛЕННЫХ КОМПАНИЙ РОССИИ \\ С УЧЕТОМ ГОСУДАРСТВЕННОЙ ПОДДЕРЖКИ \\ ОТРАСЛЕВОЙ ЭКОНОМИКИ \\ Рыкова Инна Николаевна, Кораблев Денис Владимирович Губанов Роман Сергеевич
}

В данной статье представлены результаты эмпирического исследования влияния параметров функционирования деятельности организаций реального сектора экономики на их финансовые результаты с учетом опыта господдержки отраслей промышленности России. На основе корреляционного анализа данных об объемах отгрузки продукции, товаров, работ и услуг отечественных предприятий, сформированных за период с 2008 по 2015 год, были выявлены особенности изменения экономических результатов деятельности предприятий в разрезе видов деятельности.

Определение степени влияния факторов на выручку, себестоимость и корпоративную прибыль является одной из наиболее сложных задач в процессе управления финансовыми результатами. Можно выделить ряд наиболее весомых факторов, учет которых позволит решить данную задачу: размер краткосрочных и долгосрочных займов и кредитов, сумма капитала и резервов, величина дебиторской задолженности организаций, состав себестоимости выпускаемой продукции, стоимость активов.

Актуальность данного исследования заключается в том, что в процессе формирования финансовых результатов организаций реального сектора экономики необходимо изучить не только влияние собственного капитала и привлеченных средств из внешних источников финансирования, но и особенности государственной поддержки отдельных отраслей промышленности: машиностроения, автомобилестроения, авиационной промышленности, металлургии, лесопромышленного комплекса, текстильной промышленности.

Цель данной статьи заключается в определении факторов, влияющих на себестоимость, выручку, прибыль и иные финансовые результаты организаций промышленности России с учетом эффективности господдержки ведущих отраслей экономики.

Ключевые слова: модели корреляции выручки, финансовые результаты, заемный капитал, капитал и резервы, чистая прибыль

JEL: G21

\section{Обзор литературы}

Определение финансовых результатов является одной из ключевых задач функционирования организаций в целях создания условий для безубыточной и высокоэффективной работы и их взаимовыгодного сотрудничества с финансовым сектором экономики. Организации промышленности формируют финансовые результаты не только для того, чтобы выполнить принцип самофинансирования, но и для рационального распределения капитала между источниками его поступления: частный инвестор, коммерческий банк - кредитор, покупатель - соинвестор и т.д.

\footnotetext{
${ }^{1}$ Доктор экономических наук, академик РАЕН, руководитель Центра отраслевой экономики ФГБУ «Научно-исследовательский финансовый институт», Федеральное государственное бюджетное учреждение «Научно-исследовательский финансовый институт» Министерства финансов Российской Федерации. 127006, Россия, Москва, Настасьинский переулок, д. 3 стр. 2. E-mail: rycova@yandex.ru.

${ }^{2}$ Кандидат экономических наук, научный сотрудник Центра отраслевой экономики НИФИ ФГБУ «Научно-исследовательский финансовый институт».

${ }^{3}$ Кандидат экономических наук, старший научный сотрудник Центра отраслевой экономики НИФИ ФГБУ «Научно-исследовательский финансовый институт».
} 
В ранее опубликованных исследованиях можно выделить ряд наиболее весомых факторов, которые целесообразно учитывать при расчете финансовых результатов.

В своей работе И.В. Ивашковская исследует экономическую прибыль с учетом ожиданий. Важный результат при оценке влияния факторов на финансовые результаты деятельности компаний заключается в том, что неожиданные изменения в требуемой инвесторами доходности на собственный капитал значимо отрицательно влияют на полную доходность акций. Автор подчеркивает, что важен тип отрасли, особенности бизнес-модели компании, а также влияние на мотивацию менеджеров через показатель экономической прибыли, используемый для определения величины их вознаграждения [Ивашковская, 2013].

Обобщая роль фактора ожиданий, Коупленд и Долгов предложили собственную аналитическую модель на основе экономической прибыли - управление на основе ожиданий (exресtаtions based management, $E B M$ ). По мнению авторов модели, задача заключается в том, чтобы как в принятии решений, так и в оценке их реализации учитывать необходимость превзойти три отметки ожиданий:

- ожидаемое значение бухгалтерской прибыли;

• ожидаемое значение затрат на капитал;

- ожидаемые объемы инвестиционных бюджетов и инвестиционных программ.

Несколько иной подход к оценке финансовых результатов можно наблюдать в книге Дэвида Ромера. Обобщая исследования по рассматриваемой проблеме применительно к экономике США, автор приводит взгляды ряда ученых. Так, А. Эбель, Н. Мэнкью, Л. Саммерс и Р. Зекхаузер [Abel et al., 1989] предложили способ анализа динамической эффективности в условиях неопределенности. Основной теоретический результат этой работы заключается в том, что при наличии неопределенности условием динамической эффективности является превышение чистого дохода от капитала над инвестициями. На траектории сбалансированного роста при отсутствии неопределенности - это условие эквивалентно стандартному соотношению между реальной ставкой процента и темпом экономического роста. В данном случае чистый доход от капитала равен реальной ставке процента, умноженной на запас капитала, а инвестиции - темпу экономического роста на запас капитала. Таким образом, доход от капитала превышает инвестиции тогда и только тогда, когда, когда реальная ставка процента превышает темпы экономического роста [Ромер, 2014].

Следует констатировать тот факт, что на размер реинвестирования чистой прибыли положительно влияет акционерный капитал. Прибыль организаций после уплаты налогов, как правило, находится в отрицательной зависимости от величины краткосрочных займов. Рост оборотных активов (ликвидных объектов) оказывает положительное влияние на величину чистой прибыли.

Важнейшая составляющая показателя прибыли - себестоимость произведенной и реализованной продукции - связана с факторами производства: материальными, трудовыми и информационными ресурсами, финансовыми и нематериальными активами. На практике возникает вопрос: как рациональнее оценить влияние факторов на величину прибыли? При ответе на данный вопрос целесообразно обратиться к известным моделям и алгоритмам финансового анализа. Например, влияние факторов на прибыль промышленных организаций можно оценить посредством следующих комбинаций:

- изменения себестоимости за счет структурных сдвигов в составе продукции,

- уменьшения затрат на производство единицы продукции,

- $\quad$ изменения режима экономии.

В настоящем исследовании финансовые результаты российских промышленных организаций будут всесторонне изучены с позиции влияния на прибыль и эффективность показателя себестоимости, как комплексной характеристики стоимостной оценки потребления сырья и материалов, полуфабрикатов, топлива и энергетических ресурсов, труда и человеческого капитала. 


\section{Методика, методология оценки и статистические данные}

Методика комплексного и системного изучения и измерения факторов на величину результативного показателя заключается в анализе влияния предпосылок изменения корпоративной прибыли как главенствующей составляющей финансовых результатов в зависимости от себестоимости организации и других экономических параметров.

Общеизвестно о наличии следующих методов оценки влияния факторов на результативный показатель (в контексте нашего исследования - влияния показателей на себестоимость и прибыль):

- $\quad$ детерминированный (функциональный) - результативный показатель представлен в виде произведения, частного или алгебраической суммы факторов;

- стохастический (корреляционный) - связь между результативным и факторными показателями является неполной или вероятностной;

- прямой (дедуктивный) - от общего к частному;

- обратный (индуктивный) - от частного к общему;

- одноступенчатый и многоступенчатый;

- статический и динамический;

• ретроспективный и перспективный [Романова, 2011].

Регрессионный анализ используется, чтобы определить различные меры экономической свободы [Calcagno, Benefield, 2013]. Речь идет о свободе ценообразования, свободе рынков сбыта и свободе в выборе методик расчета прибыли и себестоимости, производимой организациями продукции. Методология, применяемая нами в ходе исследования, заключается в адаптации моделей корреляционного анализа к практике функционирования российских организаций промышленности.

Метод оптимизационного моделирования заключается в оптимизации конкретного прогнозируемого показателя в зависимости от ряда условий его формирования. В качестве критерия оптимизации лучше принять максимизацию чистой прибыли [Егоршин, 2011]. С позиции Р. Бреннера, «чистая прибыль» определяется как добавленная стоимость за вычетом суммы оплаты труда, стоимости потребления капитала и косвенных налогов на бизнес, но до вычета процента. Следовательно, чтобы получить величину прибыли для частного сектора экономики и его отраслей в соответствии с данным определением, нужно сложить «чистую прибыль» и «чистый процент» [Бреннер, 2014].

Используя метод оптимизационного моделирования, целесообразно произвести расчет влияния факторов на величину прибыли и себестоимости организаций отраслей промышленности, курируемых Министерством промышленности и торговли Российской Федерации, так как данным органом управления осуществляется ряд практических задач по активизации инновационно-инвестиционных процессов в реальном секторе экономики.

Говоря о проблемах отраслевой экономики, нельзя не отметить о некоторых цифрах статистики. В 2015 году объем ВВП Российской Федерации снизился на 3,9\%. На фоне данной тенденции произошло сокращение размера валового производства на $3,3 \%$. Это наблюдается в условиях снижения качества инвестиций в основной капитал, абсолютная величина которых сократилась на $9,9 \%{ }^{4}$.

Большинство организаций промышленности ухудшили свои финансовые результаты под влиянием инфляционных процессов: рост себестоимости в 2015 году был неизбежен, так как темп инфляции составил в среднем 12,2-15\%.

В самом плохом положении с точки зрения эффективности производства оказалось машиностроение с удельным весом загрузки производственных мощностей предприятий 56\%. Наи-

\footnotetext{
${ }^{4}$ По материалам II Международного форума Финансового университета «В поисках утраченного роста» (24-26 ноября 2015 г.). Москва, 2015.
} 
большее значение загруженности производственной мощности наблюдалось на предприятиях станкостроения - $85 \%$ и черных металлов - 90\%. В среднем по промышленности России рассматриваемый показатель не превысил $61 \%$. В создавшихся экономических условиях необходимы новые «драйверы» экономического роста. Однако модель экономического развития не адаптирована к создавшимся колебаниям финансовых параметров функционирования отраслей народного хозяйства.

Рассмотрим, как складывается текущая ситуация в типичной отрасли экономики - металлургической промышленности.

Реалии таковы, что финансовые результаты отдельных предприятий металлургической промышленности не отличаются положительной динамикой, что подрывает их экономический потенциал и способность достигать инвестиционных целей в обозримом будущем. Так, например, чистая прибыль Новолипецкого металлургического комбината (далее - НЛМК) по российским стандартам бухгалтерского учета в I квартале 2016 года упала в 3,5 раза по сравнению с аналогичным периодом прошлого года - до 5,7 млрд руб.

Выручка НЛМК снизилась на 15\% - до 72,126 млрд руб., прибыль до налогообложения - в 3,3 раза, до 7,426 млрд руб. Долгосрочные обязательства компании на 31 марта 2016 года составили 137,159 млрд руб., снизившись на 7,6\% с начала года. Краткосрочные обязательства уменьшились на 7,5\% и составили 82,173 млрд руб..

Тенденции ухудшения качественных показателей развития организаций металлургии могут свидетельствовать о неспособности рассматриваемой отрасли адаптироваться к кризисным условиям и о возможном новом всплеске проявлений дефолта. Вместе с тем известно, что в антикризисном финансовом управлении предприятием широкое распространение получило прогнозирование суммы активов предприятия, а также некоторых других показателей в зависимости от изменения объема реализации продукции.

Оценка состояния отраслей экономики России не позволяет сделать утешительных для нового импульса развития народного хозяйства выводов. Это обусловлено наличием большого числа убыточных организаций. Например, при производстве транспортных средств и оборудования - 21 ед. из 100 анализируемых крупнейших компаний (табл. 1).

Таблича 1

Группировка по рентабельности продукции 100 крупнейших компаний *

\begin{tabular}{|c|c|c|c|c|c|c|}
\hline \multirow{3}{*}{ Вид производства } & \multicolumn{6}{|c|}{ Распределение компаний по уровню рентабельности, ед. } \\
\hline & \multirow{2}{*}{ 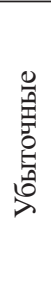 } & \multicolumn{2}{|c|}{$\begin{array}{l}\text { Низкорентабельные } \\
(0-7 \%)\end{array}$} & \multirow{2}{*}{ 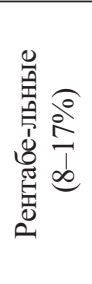 } & \multirow{2}{*}{ 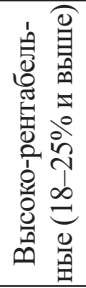 } & \multirow{2}{*}{ 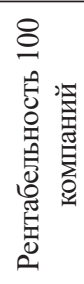 } \\
\hline & & ڤ્̊ & 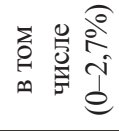 & & & \\
\hline $\begin{array}{c}\text { Производство пищевых про- } \\
\text { дуктов }\end{array}$ & 13 & 52 & 32 & 22 & 13 & 9,5 \\
\hline $\begin{array}{c}\text { Производство машин и оборудо- } \\
\text { вания }\end{array}$ & 11 & 59 & 34 & 14 & 16 & 6,2 \\
\hline $\begin{array}{c}\text { Производство транспортных } \\
\text { средств и оборудования }\end{array}$ & 21 & 58 & 37 & 15 & 6 & 2 \\
\hline $\begin{array}{c}\text { Производство, передача и рас- } \\
\text { пределение электроэнергии, газа } \\
\text { и воды }\end{array}$ & 11 & 65 & 43 & 17 & 7 & 4,97 \\
\hline
\end{tabular}

${ }^{5} \mathrm{http}: / /$ www.metalbulletin.ru/news/black/10125322 
И. Рыкова и соавторы | I. Rykova et al.51-69

\begin{tabular}{|c|c|c|c|c|c|c|}
\hline $\begin{array}{c}\text { Добыча сырой нефти, природного } \\
\text { газа, предоставление услуг в этих } \\
\text { областях }\end{array}$ & 5 & 20 & 11 & 20 & 55 & 33 \\
\hline $\begin{array}{c}\text { Добыча каменного и бурого угля, } \\
\text { торфа }\end{array}$ & 35 & 20 & 10 & 12 & 33 & 19,3 \\
\hline $\begin{array}{l}\text { Добыча полезных ископаемых, } \\
\text { кроме топливно-энергетических }\end{array}$ & 18 & 28 & 18 & 14 & 40 & 47,3 \\
\hline $\begin{array}{c}\text { Сельское и лесное хозяйство, } \\
\text { охота }\end{array}$ & 8 & 24 & 12 & 16 & 52 & 22,4 \\
\hline Строительство & 14 & 73 & 61 & 5 & 8 & 2,8 \\
\hline Транспорт & 19 & 44 & 31 & 17 & 20 & 5,4 \\
\hline
\end{tabular}

*Примечание: цุифры в строках - количество предприятий (из 100) и проценты одновременно.

Значительную долю занимает объем производства и реализации на предприятиях машиностроения для пищевой и перерабатывающей промышленности - $16 \%$, тяжелого машиностроения $-4 \%$, станкостроения $-7 \%$.

Иллюстрируя пример деятельности машиностроительных организаций в целом, отметим, что в производстве машин и оборудования ОАО «Силовые машины» по производству паровых турбин при объеме реализации продукции 16,2 млрд руб. имеет рентабельность выручки $1,2 \%$ (предприятие занимает вторую строку в рейтинге производства машин и оборудования по выручке), ОАО «Пермский моторный завод» - 6,6 млрд руб. и 1,41\%; ОАО «Автокран», Ивановской обл. - 1,9 млрд руб. и $0 \%$.

В производстве транспортных средств ОАО «Тверской вагоностроительный завод» имел объем реализации продукции 11,4 млрд руб. и рентабельность 1,62\%; ОАО «С3 Северная верфь» по строительству судов соответственно - 12,8 млрд руб. и 2,01\%; ОАО «КАМАЗ» - 50,6 млрд руб. и $0,26 \%$; и наконец ОАО «АвтоВАЗ», первый в рейтинге производства транспортных средств, $-132,5$ млрд руб. и $1,06 \%$ соответственно.

Эффективность хозяйственной деятельности ведущих предприятий рассматриваемых видов производств крайне низкая [Дасковский, Киселев, 2016].

Таким образом, на фоне увеличения объемов производства и реализации во всех отраслях промышленности наблюдаются структурные диспропорции внутриотраслевого развития экономики из-за нестабильности конъюнктуры рынка, в котором функционируют соответствующие производственные базы, и нерациональности распределения ресурсов по стадиям жизненного цикла продукции. Кроме того, ослабленной диверсификацией отличается ряд отраслей машиностроения, что не позволяет сделать вывод об эффективности его развития на современном этапе хозяйствования.

\section{Результаты оценки финансовых показателей отраслевой экономики России}

В практике оценки финансовых показателей целесообразно применять более сложные модификации метода трендов - инструменты, основанные на регрессионных моделях и выявлении математической зависимости показателя от времени. Проведенный анализ темпов роста и прироста в отраслях промышленности в разрезе видов экономической деятельности показал следующее (табл. 2). 
Средний темп роста по отрасли «Обрабатывающие производства»

\begin{tabular}{|c|c|c|c|c|c|c|c|c|}
\hline \multirow{3}{*}{ Год } & \multirow{3}{*}{$\begin{array}{l}\text { Обрабаты-ваю- } \\
\text { щие производ- } \\
\text { ства, млн. руб. }\end{array}$} & \multicolumn{2}{|c|}{$\begin{array}{l}\text { Абсолютный прирост, млн } \\
\text { руб. }\end{array}$} & \multicolumn{2}{|c|}{ Коэффициенты роста } & \multicolumn{2}{|c|}{ Коэффициенты роста } & \multirow{3}{*}{$\mathrm{A} \%$} \\
\hline & & Цепной & Базисный & Цепной & Базисный & Цепной & $\begin{array}{l}\text { Базис- } \\
\text { ный }\end{array}$ & \\
\hline & & yi-yi-1 & yi-y0 & yi/yi-1 & yi/y0 & (yi/yi-1)-1 & $\begin{array}{c}(\mathrm{yi} / \\
\mathrm{y} 0)-1 \\
\end{array}$ & \\
\hline 2008 & 16863615 & & & & & & & \\
\hline 2009 & 14351985 & $-2511630,0$ & -2511630 & 0,8511 & 0,8511 & $-0,1489$ & $-0,1489$ & 168636,15 \\
\hline 2010 & 18880737 & 4528752,0 & 2017122 & 1,3155 & 1,1196 & 0,3155 & 0,1196 & 143519,85 \\
\hline 2011 & 22813279 & 3932542,0 & 5949664 & 1,2083 & 1,3528 & 0,2083 & 0,3528 & 188807,37 \\
\hline 2012 & 25110611 & 2297332,0 & 8246996 & 1,1007 & 1,4890 & 0,1007 & 0,4890 & 228132,79 \\
\hline 2013 & 27132731 & 2022120,0 & 10269116 & 1,0805 & 1,6090 & 0,0805 & 0,6090 & 251106,11 \\
\hline 2014 & 30117668 & 2984937,0 & 13254053 & 1,1100 & 1,7860 & 0,1100 & 0,7860 & 271327,31 \\
\hline 2015 & 31963784 & 1846116,0 & 15100169 & 1,0613 & 1,8954 & 0,0613 & 0,8954 & 301176,68 \\
\hline & 187234410 & $\Sigma=15100169$ & & $\begin{array}{c}\Pi= \\
1,8954\end{array}$ & & $\begin{array}{c}1,8954-1= \\
0,8954\end{array}$ & & \\
\hline Cpe & иe: 23404301,3 & 2157167,0 & & $\begin{array}{c}7 \sqrt{ } 1,896= \\
1,096\end{array}$ & & $\begin{array}{c}1,096-1= \\
0,096\end{array}$ & & \\
\hline
\end{tabular}

Темп роста по данной отрасли составил $109,6 \%$ в среднем за год за анализируемый период. Показатель среднего прироста по отрасли обрабатывающие производства достиг значения 9,6\%. Применяя метод трендов в анализе финансовых показателей и динамику показателя объема отгруженных товаров за предыдущие годы (2008-2015), можно сделать его прогноз на следующий год (2016).

Так как рассматриваемый показатель по объему обрабатывающих производств увеличивается за год в среднем на 9,6\%, следовательно, расчет его значения на плановый год - 2016 год осуществляется на основе произведения 31963784 млн руб. на 1,16. В результате расчетов получим плановую величину показателя объема обрабатывающих производств на 2016 год - 3068 523,264 млн руб. Аналогичный расчет целесообразно произвести и в отношении отраслей «производство и распределение энергии, газа и воды», исходные данные для прогноза которых представлены в таблице 3 .

Таблица 3

Средний темп роста по отрасли «Производство и распределение энергии, газа и воды»

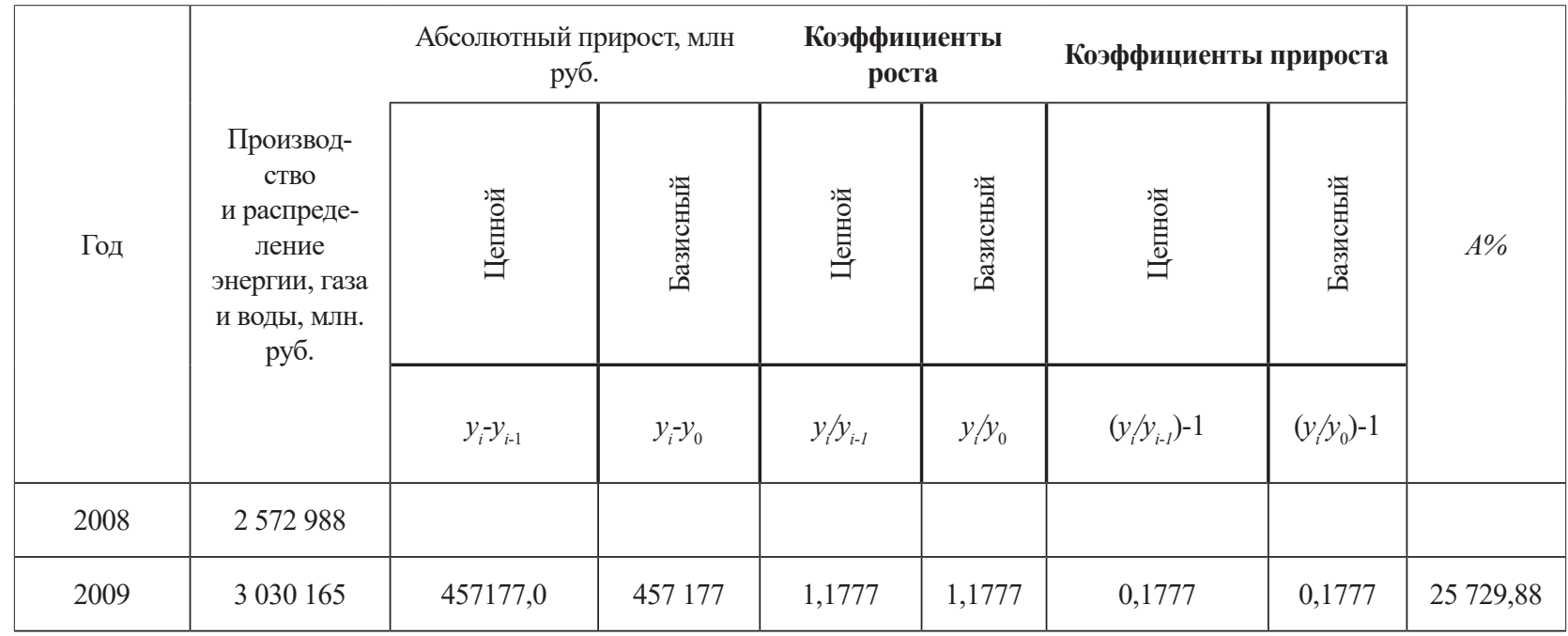


И. Рыкова и соавторы | I. Rykova et al.51-69

\begin{tabular}{|c|c|c|c|c|c|c|c|c|}
\hline 2010 & 3665280 & 635115,0 & 1092292 & 1,2096 & 1,4245 & 0,2096 & 0,4245 & 30301,65 \\
\hline 2011 & 4219137 & 553857,0 & 1646149 & 1,1511 & 1,6398 & 0,1511 & 0,6398 & 36652,8 \\
\hline 2012 & 4160147 & $-58990,0$ & 1587159 & 0,9860 & 1,6169 & $-0,0140$ & 0,6169 & 42191,37 \\
\hline 2013 & 4491574 & 331427,0 & 1918586 & 1,0797 & 1,7457 & 0,0797 & 0,7457 & 41601,47 \\
\hline 2014 & 4712009 & 220435,0 & 2139021 & 1,0491 & 1,8313 & 0,0491 & 0,8313 & 44915,74 \\
\hline 2015 & 4646449 & $-65560,0$ & 2073461 & 0,9861 & 1,8059 & $-0,0139$ & 0,8059 & 47120,09 \\
\hline \multicolumn{2}{|c|}{$\Sigma=31497749,0$} & $\Sigma=2073461$ & & $\Pi=1,806$ & & $1,806-1=806$ & & \\
\hline \multicolumn{2}{|c|}{ Средние: 3937 218,6 } & 296208,7 & & $\begin{array}{c}7 \sqrt{ } 1,806= \\
1,089\end{array}$ & & $1,089-1=0,089$ & & \\
\hline
\end{tabular}

Следует констатировать, что причинно-следственная связь между прибылью и сроками финансовых обязательств компании изучена недостаточно. Сводные данные о среднегодовых темпах роста и прироста по всем видам экономической деятельности представлены в таблице 4.

Таблиича 4

\section{Среднегодовые темпы роста и прироста по видам экономической деятельности}

\begin{tabular}{|c|c|c|c|c|}
\hline Отрасли & $\begin{array}{c}\text { Отгрузка } \\
\text { в среднем } \\
\text { в год, млн руб. }\end{array}$ & $\begin{array}{c}\text { Среднегодовой } \\
\text { абсолютный } \\
\text { прирост, млн руб. }\end{array}$ & $\begin{array}{c}\text { Среднегодовые } \\
\text { темпы роста, } \\
\%\end{array}$ & $\begin{array}{c}\text { Среднегодовые } \\
\text { темпы прироста, \% }\end{array}$ \\
\hline Добыча полезных ископаемых & 8118186,3 & 869658,6 & 111,6 & 11,6 \\
\hline Обрабатывающие производства & 23404301,3 & 2157167,0 & 109,6 & 9,6 \\
\hline $\begin{array}{c}\text { Производство и распределение } \\
\text { электроэнерги, газа и воды }\end{array}$ & 3937218,6 & 296208,7 & 108,8 & 8,8 \\
\hline
\end{tabular}

Динамика объема отгруженных товаров и услуг по отраслям в 2008-2015 годах (рис. 1) свидетельствует о тенденции увеличения стоимостных показателей выручки в течение всего горизонта оценки. Однако спад объемных показателей приходился на период 2009 года, в котором образовался финансовый кризис России, сопровождающийся дисбалансом финансовых потоков в банковском секторе, стройиндустрии и большинстве производственных предприятий.

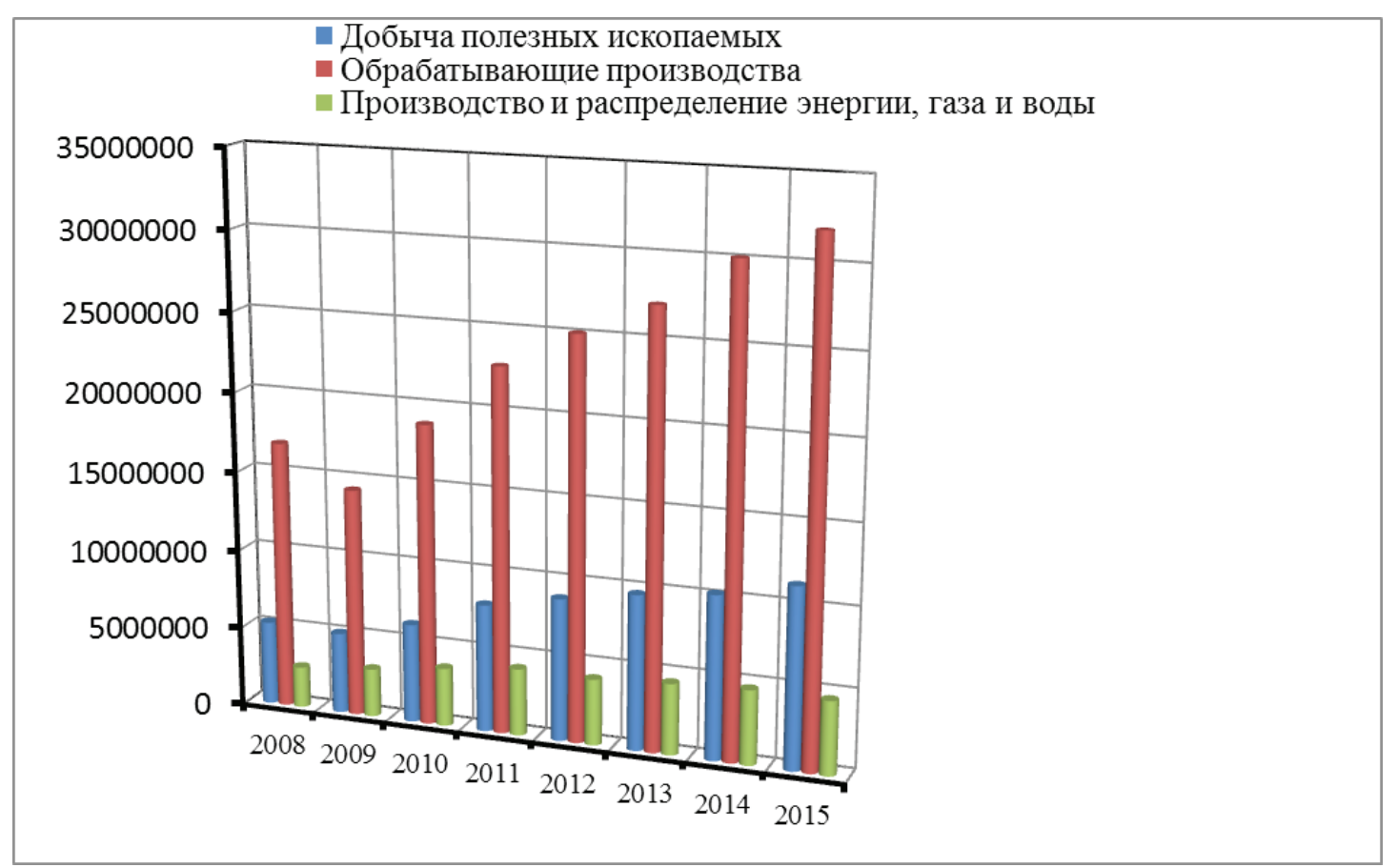

Рисунок 1. Динамика объема отгруженных товаров и услуг по отраслям 
Вполне очевидно, что для расчета чистой прибыли российских промышленных организаций важно использовать алгоритм, в основу которого положен принцип формирования добавленной стоимости. В этой связи обратимся к размеру добавленной стоимости, создаваемой российскими предприятиями отдельных отраслей промышленности (табл. 5).

Таблица 5

Валовая добавленная стоимость по видам экономической деятельности, млрд руб.

\begin{tabular}{|c|c|c|c|c|c|c|c|c|c|c|}
\hline $\begin{array}{c}\text { Отрасли про- } \\
\text { мышленности }\end{array}$ & \multicolumn{3}{|c|}{ Анализ } & \multicolumn{5}{c|}{ Прогноз } \\
\cline { 2 - 11 } & 2012 & 2013 & 2014 & 2015 & 2016 & 2017 & 2018 & 2019 & 2020 & 2021 \\
\hline $\begin{array}{c}\text { Производство пи- } \\
\text { щевых продуктов }\end{array}$ & 1132 & 1244 & 1266 & 1366 & 1289 & 1361 & 1456 & 2001 & 3450 & 4560 \\
\hline $\begin{array}{c}\text { Производство } \\
\text { табачных изделий }\end{array}$ & 87,3 & 95,6 & 90,3 & 96 & 92 & 89 & 74 & 89 & 92 & 101 \\
\hline $\begin{array}{c}\text { Текстильное про- } \\
\text { изводство }\end{array}$ & 44,5 & 47 & 45,8 & 46 & 48 & 49 & 50 & 51 & 52 & 52 \\
\hline $\begin{array}{c}\text { Производство } \\
\text { одежды; выделка } \\
\text { и крашение меха }\end{array}$ & 68,6 & 77,2 & 78 & 77 & 78 & 79 & 80 & 81 & 82 & 86 \\
\hline $\begin{array}{c}\text { Производство } \\
\text { кожи, изделий из } \\
\text { кожи и производ- } \\
\text { ство обуви }\end{array}$ & 21,8 & 21,8 & 18 & 24,6 & 25,6 & 27 & 29 & 30 & 31 & 31 \\
\hline $\begin{array}{c}\text { Производство } \\
\text { целлюлозы, дре- } \\
\text { весной массы }\end{array}$ & 129,5 & 134,8 & 153,3 & 156 & 158 & 149 & 189 & 171 & 182 & 195 \\
\hline
\end{tabular}

Отмечается повышение валовой добавленной стоимости по ряду производств: пищевых продуктов с 1131,6 млрд руб. в 2012 году до 1366 млрд руб. в 2015 году, текстильной промышленности - с 44,5 млрд руб. в 2012 году до 46 млрд руб. в 2015 году и т.д.

Итак, добавленная стоимость большинства видов производства возрастет в прогнозном периоде, так как тарифы на услуги и потребляемое сырье увеличиваются пропорционально росту цен. Наибольшее увеличение валовой добавленной стоимости произойдет в организациях пищевой промышленности - к 2021 году в 4 раза по сравнению с отчетным периодом. Наименьший прирост валовой добавленной стоимости будет достигнут в отраслях текстильного производства.

В таблице 6 представлены данные об объеме производства и реализации продукции, производимой в отраслях промышленности Минпромторга России.

Таблица 6

Динамика объема отгруженных товаров собственного производства за 2010-2014 годы в отраслях промышленности, курируемых Минпромторгом России

\begin{tabular}{|c|c|}
\hline Отрасль & $\begin{array}{c}\text { Динамика } \\
2014 \text { в \% к 2010 }\end{array}$ \\
\hline Автомобильная промышленность & 192 \\
\hline Авиационная промышленность & 179 \\
\hline Радиоэлектронная промышленность & 163 \\
\hline Строительно-дорожное и коммунальное машиностроение & 72 \\
\hline Машиностроение для пищевой и перерабатывающей промышленности & 132 \\
\hline Станкостроение & 144 \\
\hline Нефтегазовое машиностроение & 136 \\
\hline Судостроение & 110 \\
\hline Сельхозмашиностроение & 157 \\
\hline Энергетическое машиностроение & 101 \\
\hline Тяжелое машиностроение & 87 \\
\hline
\end{tabular}


И. Рыкова и соавторы | I. Rykova et al.51-69

\begin{tabular}{|c|c|}
\hline Лесопромышленный комплекс & 250 \\
\hline Фармацевтическая промышленность & 138 \\
\hline Медицинская промышленность & 124 \\
\hline Торговые сети & 154 \\
\hline Легкая промышленность & 127 \\
\hline Металлургия & 126 \\
\hline ИТОГО & 115 \\
\hline производство кожи, изделий из кожи и производство обуви & 141 \\
\hline
\end{tabular}

По ряду отраслей промышленности наблюдался спад производства, что подтверждается отрицательными темпами роста объемных показателей за 2010-2014 годы: в отрасли строительно-дорожного и коммунального машиностроения на 28\%; в отрасли тяжелого машиностроения - на 13\%. За анализируемый период энергетическое машиностроение характеризовалось незначительным увеличением объемов производства, так как прирост продукции составил $1 \%$. Существенное увеличение объема отгруженных товаров произошло в торговых сетях на $54 \%$.

\section{Финансовая поддержка государством отраслей экономики России и зарубежный опыт}

Реализация задач импортозамещения в сфере гражданской промышленности осуществляется в рамках ряда государственных программ Российской Федерации, что позволит обеспечить независимое от внешнего воздействия развитие реального сектора экономики ${ }^{6}$. Бюджетное финансирование в сфере промышленности России распределено с учетом приоритетов программных обязательств и задач. Так, наибольшее финансовое обеспечение приходится на государственную программу «Развитие промышленности и повышение ее конкурентоспособности», которое составляет за период с 2014 по 2016 год 459,45 млрд руб. (табл. 7).

Таблица 7

Бюджетное финансирование в сфере гражданской промышленности в рамках государственных программ Российской Федерации, млрд руб.*

\begin{tabular}{|c|c|c|c|c|}
\hline Наименование государственной программы & 2014 год & 2015 год & 2016 год & $\begin{array}{c}\text { Итого за } 3 \\
\text { года }\end{array}$ \\
\hline $\begin{array}{c}\text { Развитие промышленности и повышение ее конкурентоспособ- } \\
\text { ности }\end{array}$ & 153,58 & 149,27 & 156,6 & 459,45 \\
\hline $\begin{array}{l}\text { Развитие авиационной промышленности } \\
\text { на 2013-2025 годы } \\
\end{array}$ & 59,11 & 85,1 & 52,9 & 197,11 \\
\hline $\begin{array}{c}\text { Развитие судостроения и техники для освоения шельфовых } \\
\text { месторождений на 2013-2030 годы }\end{array}$ & 24,71 & 9,5 & 17,7 & 51,91 \\
\hline $\begin{array}{l}\text { Развитие электронной и радиоэлектронной промышленности } \\
\text { на 2013-2025 годы } \\
\end{array}$ & 14,69 & 11,8 & 12,8 & 39,29 \\
\hline $\begin{array}{c}\text { Развитие фармацевтической и медицинской промышленности } \\
\text { на 2013-2020 годы }\end{array}$ & 13,49 & 12,9 & 16,9 & 43,29 \\
\hline ВСЕГО & 265,58 & 268,57 & 256,90 & 791,05 \\
\hline
\end{tabular}

* Федеральное казначейство Российской Федераџии. Расходы федерального бюджета на развитие гражданской промышленности в 2014 году составили 0,34 \% валового внутреннего продукта.

Однако по большинству госпрограмм финансирование в динамике за три года снижается. Так, наблюдается, что по госпрограмме «Развитие авиационной промышленности на 2013-2025

${ }^{6}$ Министерство промышленности и торговли Российской Федерации: официальный сайт [Электронный ресурс]. URL: http://minpromtorg.gov.ru/open_ministry/declaration/main (дата обращения: 23.01.2016 г.).

Министерство промышленности и торговли Российской Федерации: официальный сайт [Электронный ресурс]. URL: http://minpromtorg.gov.ru/open_ministry/declaration/import (дата обращения: 23.01.2016 г.). Примечание: $35+23.3+24.61+29.6$

Федеральная служба государственной статистики: официальный сайт [Электронный ресурc]. URL: http://www. gks.ru/free_doc/new_site/vvp/130116/tab10a.htm (дата обращения: 23.01.2016 г.). 
годы» уменьшение выделенных бюджетных средств составил около 7 млрд руб., по госпрограмме «Развитие электронной и радиоэлектронной промышленности на 2013-2025 годы» сокращение финансирования достигнет порядка 2 млрд руб.

В целях сравнительного анализа эффективности в таблице 8 приведена отраслевая структура валовой добавленной стоимости отраслей экономики в разрезе субъектов Российской Федерации.

Таблица 8

Отраслевая структура валовой добавленной стоимости отраслей экономики в разрезе субъектов Российской Федерации в 2005 и 2013 годах, \% (в текущих основных ценах; в процентах к итогу) *

\begin{tabular}{|c|c|c|c|c|c|c|c|c|c|}
\hline Регионы & Годы & $\begin{array}{l}\text { Всего } \\
\text { (итог) }\end{array}$ & \begin{tabular}{|c|} 
Добыча \\
полезных \\
ископаемых \\
\end{tabular} & $\begin{array}{c}\text { Обрабаты-ва- } \\
\text { ющие произ- } \\
\text { водства }\end{array}$ & $\begin{array}{l}\text { Сельское } \\
\text { хозяйство }\end{array}$ & \begin{tabular}{|} 
Произ- \\
водство \\
электро- \\
энергии
\end{tabular} & $\begin{array}{l}\text { Строи- } \\
\text { тельство }\end{array}$ & $\begin{array}{c}\text { Оптовая и } \\
\text { розничная } \\
\text { торговля }\end{array}$ & $\begin{array}{l}\text { Транспорт } \\
\text { и связь }\end{array}$ \\
\hline \multirow{2}{*}{$\begin{array}{c}\text { Российская Федерация } \\
\text { из суммы субъектов }\end{array}$} & 2005 & 100 & 12,8 & 18,5 & 5,2 & 3,8 & 5,7 & 21,8 & 10,6 \\
\hline & 2013 & 100 & 10,8 & 17,4 & 4,2 & 3,9 & 6,8 & 18,0 & 10,0 \\
\hline \multirow{2}{*}{$\begin{array}{c}\text { Центральный } \\
\text { федеральный округ }\end{array}$} & 2005 & 100 & 0,8 & 17,1 & 2,9 & 3,9 & 5,1 & 35,2 & 8,7 \\
\hline & 2013 & 100 & 0,7 & 17,5 & 2,8 & 4,2 & 5,1 & 26,3 & 9,6 \\
\hline \multirow{2}{*}{$\begin{array}{c}\text { Северо-Западный } \\
\text { федеральный округ }\end{array}$} & 2005 & 100 & 7,6 & 24,0 & 3,8 & 4,1 & 6,6 & 16,3 & 14,1 \\
\hline & 2013 & 100 & 7,1 & 19,9 & 2,0 & 4,1 & 7,4 & 15,3 & 12,1 \\
\hline \multirow{2}{*}{ Южный федеральный округ } & 2005 & 100 & 2,8 & 18,6 & 13,1 & 4,6 & 7,9 & 16,8 & 13,7 \\
\hline & 2013 & 100 & 3,2 & 15,1 & 10,1 & 3,1 & 13,9 & 16,7 & 10,8 \\
\hline \multirow{2}{*}{$\begin{array}{c}\text { Северо-Кавказский феде- } \\
\text { ральный округ }\end{array}$} & 2005 & 100 & 2,3 & 10,7 & 18,9 & 4,7 & 8,4 & 18,1 & 12,3 \\
\hline & 2013 & 100 & 0,8 & 8,6 & 13,8 & 3,5 & 11,0 & 20,5 & 7,2 \\
\hline \multirow{2}{*}{$\begin{array}{c}\text { Приволжский } \\
\text { федеральный округ }\end{array}$} & 2005 & 100 & 15,1 & 24,0 & 8,3 & 4,0 & 6,2 & 13,4 & 10,4 \\
\hline & 2013 & 100 & 12,4 & 24,4 & 6,1 & 3,7 & 7,1 & 13,7 & 8,3 \\
\hline \multirow{2}{*}{$\begin{array}{c}\text { Уральский федеральный } \\
\text { округ }\end{array}$} & 2005 & 100 & 43,5 & 11,1 & 2,4 & 2,1 & 4,5 & 15,7 & 8,1 \\
\hline & 2013 & 100 & 34,8 & 13,5 & 2,1 & 3,2 & 6,6 & 11,1 & 9,6 \\
\hline \multirow{2}{*}{$\begin{array}{c}\text { Сибирский федеральный } \\
\text { округ }\end{array}$} & 2005 & 100 & 9,4 & 27,9 & 7,3 & 4,7 & 4,7 & 12,4 & 13,2 \\
\hline & 2013 & 100 & 12,5 & 19,1 & 5,7 & 4,1 & 5,7 & 12,0 & 11,4 \\
\hline \multirow{2}{*}{$\begin{array}{l}\text { Дальневосточный } \\
\text { федеральный округ }\end{array}$} & 2005 & 100 & 14,9 & 7,7 & 5,7 & 5,3 & 9,3 & 13,4 & 15,2 \\
\hline & 2013 & 100 & 26,5 & 5,4 & 3,0 & 4,2 & 6,8 & 11,0 & 13,3 \\
\hline
\end{tabular}

*http://www.gks.ru/bgd/regl/b15_14p/IssWWW.exe/Stg/d02/10-04.doc

Обращает на себя внимание факт увеличения доли строительства в ЮФО с 7,9\% в 2005 году до 13,9\% в 2013 году. На этом фоне уменьшилась доля обрабатывающих производств с 18,6\% году до 15,1\% в 2013 году. Данные тенденции продолжают и в 2014-2016 годах оказывать свое влияние на отраслевую экономику региона в частности и Российской Федерации в целом.

Валовая добавленная стоимость - не единственный показатель, раскрывающий экономический потенциал экономики страны, ее создание возможно только при условии рационального потребления материальных, трудовых и финансовых ресурсов, используемых для обеспечения устойчивого развития отраслей экономики.

Вместе с тем отраслевая экономика неспособна развиваться хаотично без поддержки государства и дополнительного финансирования, полученного от внешних контрагентов в силу недостаточности собственного капитала промышленных предприятий или ограничений использования чистой прибыли, обусловленных необходимостью компенсации издержек по обслуживанию обязательств перед учредителями по дивидендным выплатам.

Проведенный анализ государственной поддержки отраслей промышленности (табл. 9) позволяет сделать следующие экспертные оценки. В выборку были включены только те отрасли, которые получали господдержку в 2014 году. Отсутствие финансирования промышленности из бюджета Российской Федерации по государственным программам дает основания для невключения остальных отраслей экономики в оценку для целей настоящего исследования. 
Эффективность поддержки отраслей промышленности, курируемых Минпромторгом России в 2014 году

\begin{tabular}{|c|c|c|c|c|c|c|}
\hline Отрасль* & $\begin{array}{c}\text { GP } \\
\text { Объем господ- } \\
\text { держки, млрд } \\
\text { руб. }\end{array}$ & $\begin{array}{c}Z \\
\text { Затраты**, } \\
\text { млрд руб. } \\
\text { (с. } 2+\text { с. } \\
3+\text { c. } 4+ \\
\text { с. } 5+\text { c. } 6 \\
\text { следующей } \\
\text { таблишы) }\end{array}$ & $\begin{array}{c}\text { P } \\
\text { При- } \\
\text { быль, } \\
\text { млрд руб. }\end{array}$ & $\begin{array}{c}\text { VP } \\
\text { Валовая } \\
\text { продукция } \\
\text { млрд руб. } \\
\text { (гр. } 3 \text { + гр. } \\
\text { 4) }\end{array}$ & $\begin{array}{c}\text { Прирост } \\
\text { продукции от } \\
\text { господдержки, } \\
\text { млрд руб. (гр. } 5 \\
\times \text { гр. } 2 \div \text { гр. 3) }\end{array}$ & $\begin{array}{c}\mathbf{E} \\
\text { Эффективность } \\
\text { поддержки (гр. } 6 \\
\div \text { гр. 2) }\end{array}$ \\
\hline 1 & 2 & 3 & 4 & 5 & 6 & 7 \\
\hline $\begin{array}{c}\text { Автомобильная про- } \\
\text { мышленность }\end{array}$ & 99,251 & 1655,4 & 30 & 1685,4 & 101,1 & 1,02 \\
\hline Станкостроение & 2,277 & 2617 & 98 & 2715 & 2,4 & 1,04 \\
\hline $\begin{array}{c}\text { Оборонно-промыш- } \\
\text { ленный комплекс }\end{array}$ & 7,942 & 983 & 50 & 1033 & 8,3 & 1,05 \\
\hline $\begin{array}{c}\text { Транспортное маши- } \\
\text { ностроение }\end{array}$ & 7,324 & 2939,5 & $-14,5$ & 2925 & 7,3 & 0,10 \\
\hline $\begin{array}{c}\text { Лесопромышлен- } \\
\text { ный комплекс }\end{array}$ & 0,731 & 863,2 & $-12,2$ & 851 & 0,7 & 0,99 \\
\hline $\begin{array}{c}\text { Легкая промышлен- } \\
\text { ность }\end{array}$ & 1,534 & 267,3 & 19,2 & 286,5 & 1,6 & 1,07 \\
\hline $\begin{array}{c}\text { Индустрия детских } \\
\text { товаров }\end{array}$ & 0,995 & 13,8 & 0,7 & 14,5 & 1,0 & 1,05 \\
\hline
\end{tabular}

* Постановление Правительства Российской Федерации от 15 апреля 2014 № 328 «Об утверждении государственной программы Российской Федерации «Развитие промышленности и повышение ее конкурентоспособности» // Россия в циифрах. 2015: Kрат. стат. сб. / Росстат. М., 2015. - 545 c.

**Затраты - сумма материальных расходов, заработной платы, отчислений на сочиальные нужды, амортизации и прочих расходов.

Наивысший прирост полученной валовой продукции от государственной поддержки достигнут в автомобильной промышленности - 101 млрд руб. На втором месте находится оборонно-промышленный комплекс - 8,3 млрд руб., третье место занимает отрасль транспортного машиностроения - 7,3 млрд руб.

Итак, анализ динамики показал, что наименьший прирост за анализируемый период наблюдался в лесопромышленном комплексе - 0,7 млрд руб., а затем следует индустрия детских товаров - 1,0 млрд руб. Далее произведем группировку затрат, учитываемых при расчете эффективности господдержки отраслей промышленности, деятельность которых регулируется Министерством промышленности и торговли России (табл. 10).

Оценка структуры затрат свидетельствует, что наиболее материалоемким является станкостроение, удельный вес материальных затрат которого в себестоимости продукции в 2014 году составил $80 \%$.

Таблица 10

Затраты на производство и реализацию, входящие в себестоимость продукции отраслей промышленности, курируемых Минпромторгом России в 2014 году, млрд руб.

\begin{tabular}{|c|c|c|c|c|c|}
\hline Отрасль & $\begin{array}{c}\text { MZ } \\
\text { Материальные } \\
\text { затраты }\end{array}$ & $\begin{array}{c}\text { ZP } \\
\text { Заработная } \\
\text { плата }\end{array}$ & $\begin{array}{c}\text { SV } \\
\text { Страховые } \\
\text { взносы }\end{array}$ & $\begin{array}{c}\text { A } \\
\text { Амортизация }\end{array}$ & $\begin{array}{c}\text { PZ } \\
\text { Прочие затраты }\end{array}$ \\
\hline 1 & 2 & 3 & 4 & 5 & 6 \\
\hline $\begin{array}{c}\text { Автомобильная промыш- } \\
\text { ленность }\end{array}$ & 1141,55 & 331,08 & 106,5 & 53,55 & 22,72 \\
\hline Станкостроение & 2105,6 & 350,05 & 121,05 & 30 & 10,3 \\
\hline $\begin{array}{c}\text { Оборонно-промышленный } \\
\text { комплекс }\end{array}$ & 652,01 & 245,09 & 73,5 & 10,4 & 2 \\
\hline $\begin{array}{c}\text { Транспортое машино- } \\
\text { строение }\end{array}$ & 2388 & 368 & 121,72 & 60 & 1,78 \\
\hline
\end{tabular}


И. Рыкова и соавторы | I. Rykova et al.51-69

\begin{tabular}{|c|c|c|c|c|c|}
\hline $\begin{array}{c}\text { Лесопромышленный } \\
\text { комплекс }\end{array}$ & 621,36 & 159,08 & 54,06 & 25 & 3,7 \\
\hline Легкая промышленность & 165,3 & 56,3 & 18,9 & 20 & 7 \\
\hline $\begin{array}{c}\text { Индустрия детских } \\
\text { товаров }\end{array}$ & 8,66 & 3,2 & 1,1 & 0,75 & 0,09 \\
\hline
\end{tabular}

Вместе с тем известно, что в наибольшей степени отечественные машиностроители преуспели в производстве материалоемкого оборудования и машин. Если материалоемкое оборудование (станки-качалки, вышки, трубы и др.) нефтегазового комплекса успешно конкурирует с импортным (ЕС плюс Китай), то инновационное оборудование и машины (системы контроля процессов бурения, разведки) отечественного производства, комплектуемые импортными приборами, датчиками, средствами связи и управления, - недостаточно конкурентоспособны и импортозависимы. По оценкам, материалоемкое оборудование составляет в российских компаниях 80-95\%, а инновационное оборудование отечественного производства - 30-40\%. Иначе говоря, доля пассивной части отечественного оборудования приближается к 100\%, а доля активной части составляет менее 50\% [Дмитриевский, Комков, Кротова, Романцов, 2016].

Отрасли, активно экспортирующие и слабо зависящие от импорта, - металлургия, химия и нефтехимия, производство кожи, сельское хозяйство - в результате ослабления национальной валюты кратно повысили свою конкурентоспособность на внешних рынках. При этом важно отметить, что если попытки государства по введению ограничений на торгуемость товаров, т.е. ценовых и технических форм контроля за экспортом (введение экспортных пошлин на зерно и металлы, физическое закрытие экспортных терминалов, ограничения в предоставлении вагонов на экспортном направлении) с целью не допустить дефицита продукции на внутреннем рынке увенчались успехом, то положение данных отраслей могло бы быть противоположным [Идрисов, 2016].

Сравнение российского и зарубежного опыта государственной поддержки развития отраслевой экономики позволило выявить ряд закономерностей в механизме и путях реализации оптимистического сценария реализации модели финансирования. Из опыта развивающихся стран, переживших последствия экономического кризиса, становятся ясной причина торможения процессов господдержки: неэффективность выбранной модели экономического роста. Речь идет не только о нерациональной структуре валовой добавленной стоимости продукции, работ и услуг в разрезе видов экономической деятельности, но и о нетипичной для кризиса финансовой политике. Так, например, Бразилия была подвергнута экономическим процессам, при которых в 2011 году упали цены на железную руду. Основной сырьевой ресурс для развития отраслей экономики не обеспечил её эффект при формировании ВВП и расчете добавленной стоимости товаров. В результате государство следовало курсу увеличения «бюджетных трат», что сопровождалось выделением дополнительных расходов на финансирование промышленности, сферы кредитования, населения. Кризис неплатежей в экономике Бразилии достиг состояния, при котором последовало троекратное увеличение инфляции, финансовые оттоки на порядок превысили поступление денег в государственный бюджет. Это в немалой степени отрицательно повлияло на экономические итоги государственной поддержки: под угрозой оказалась политическая устойчивость страны.

Опыт Венесуэлы, оказавшейся в условиях большого числа кризисных явлений, характеризуется выбором финансовой политики, при которой организация господдержки не способствовала наращению валовой добавленной стоимости. Речь идет о стратегии заимствований, которая была реализована неэффективно, и как следствие - недопустимое повышение государственного долга, резкое колебание фактического курса национальной валюты от рыночного курса, падение реальной заработной платы и рост безработицы.

Все эти примеры свидетельствуют о необходимости грамотного подхода к реформированию экономической системы, которое нельзя рассматривать в отрыве от финансовых результатов деятельности промышленных предприятий, активно участвующих в создании валовой добавленной стоимости и обеспечивающих вклад в ВВП страны. 


\section{Оценка экономических факторов и их влияние на себестоимость промышленных организаций России}

Используя стохастический (корреляционный) метод оценки, произведем расчет влияния ряда экономических факторов на размер себестоимости организаций ведущих отраслей промышленности, входящих в отраслевой срез ответственности Министерства промышленности и торговли Российской Федерации, среди которых: автомобилестроение, судостроение, транспортное машиностроение, металлургия. Для оценки влияния факторов на себестоимость отгруженной продукции в организациях нами отобраны следующие факторы: активы, нематериальные активы (НА), дебиторская задолженность (ДЗ), кредиторская задолженность (КЗ), краткосрочные (ЗК) и долгосрочные займы и кредиты (ЗД), капитал (К), себестоимость (СС). В таблице 11 сведены суммарные значения показателей по предприятиям для каждой отрасли за 2014 год.

Можно провести традиционный корреляционно-регрессионный анализ с использованием пакета прикладных программ Excel; предположим, что между выбранными факторами и себестоимостью имеется линейная зависимость. Матрица парных линейных корреляций приведена в таблице 12.

Таблица 12

Матрица парных корреляций

\begin{tabular}{|c|c|c|c|c|c|c|c|c|}
\hline Показатели & Активы & $\begin{array}{c}\text { Н/м акти- } \\
\text { вы }\end{array}$ & Д/зад & К/зад & $\begin{array}{c}\text { 3 и к } \\
\text { (долг) }\end{array}$ & 3 и к (кратк) & Капитал & С/С \\
\hline Активы & 1 & & & & & & & \\
\hline Н/м активы & 0,8977 & 1 & & & & & & \\
\hline Д/зад & 0,9796 & 0,9471 & 1 & & & & & \\
\hline К/зад & 0,9588 & 0,8475 & 0,9665 & 1 & & & & \\
\hline З и к(долг) & 0,9862 & 0,9116 & 0,9621 & 0,9087 & 1 & & & \\
\hline З и к (кратк) & 0,8938 & 0,8218 & 0,8434 & 0,7760 & 0,9003 & 1 & & \\
\hline Капитал & 0,9389 & 0,7544 & 0,8737 & 0,8825 & 0,9224 & 0,9002 & 1 & 1 \\
\hline С/С & 0,8971 & 0,6890 & 0,8193 & 0,8185 & 0,8788 & 0,9066 & 0,9055 & 1 \\
\hline
\end{tabular}

Значения коэффициентов весьма высоки, факторы коррелированы между собой. Высокая мультиколлинеарность факторов не дает возможности получить надежную множественную линейную модель для анализа. Представляется целесообразным рассмотреть модели парной регрессии себестоимости на каждый фактор в отдельности.

Таблица 11

Суммарные значения показателей по предприятиям для каждой отрасли за 2014 год, тыс. руб.

\begin{tabular}{|c|c|c|c|c|c|c|c|c|}
\hline Отрасли & Активы & НА & Д3 & К3 & Д3 & ЗК & К & СС \\
\hline $\begin{array}{c}\text { Строитель- } \\
\text { но-дорожно- } \\
\text { коммунальное } \\
\text { машиносто- } \\
\text { ение }\end{array}$ & 71851580 & 702663 & 17439010 & 22487445 & 16646979 & 30111175 & -3277614 & 52435041 \\
\hline $\begin{array}{c}\text { Машино- } \\
\text { строение для } \\
\begin{array}{c}\text { пищевой и } \\
\text { перераба- } \\
\text { тывающей } \\
\text { промышлен- } \\
\text { ности }\end{array}\end{array}$ & 9778346 & 1603 & 1853195 & 2885616 & 2159565 & 1650614 & 2751378 & 7705928 \\
\hline $\begin{array}{c}\text { Станкостро- } \\
\text { ение }\end{array}$ & 16150227 & 143051 & 5338352 & 5236778 & 2869605 & 2496516 & 5237328 & 10643877 \\
\hline
\end{tabular}


И. Рыкова и соавторы | I. Rykova et al.51-69

\begin{tabular}{|c|c|c|c|c|c|c|c|c|}
\hline $\begin{array}{c}\text { Нефтегазовое } \\
\text { машиностро- } \\
\text { ение }\end{array}$ & $\begin{array}{c}185167 \\
841\end{array}$ & 642638 & 65527092 & 67718984 & 27013163 & 32314141 & 50880327 & $\begin{array}{c}123504 \\
724\end{array}$ \\
\hline $\begin{array}{c}\text { Сельхозмаши- } \\
\text { ностроение }\end{array}$ & 27396505 & 13748 & 4936345 & 6372389 & 6044086 & 5654190 & 8630323 & 24972788 \\
\hline $\begin{array}{c}\text { Энергетиче- } \\
\text { ское машино- } \\
\text { строение }\end{array}$ & $\begin{array}{c}180800 \\
991\end{array}$ & 1213063 & 74946985 & 76190003 & 26804468 & 41301943 & 31361828 & $\begin{array}{c}142947 \\
700\end{array}$ \\
\hline $\begin{array}{c}\text { Тяжелое } \\
\text { машиностро- } \\
\text { ение }\end{array}$ & 77913679 & 488193 & 20834758 & 19416931 & 14310769 & 24020565 & 14367049 & 40520715 \\
\hline $\begin{array}{c}\text { Лесопро- } \\
\text { мышленный } \\
\text { комплекс }\end{array}$ & $\begin{array}{c}155428 \\
099\end{array}$ & 1014905 & 28380857 & 26159659 & 57213490 & 20192837 & 44550219 & 92484324 \\
\hline $\begin{array}{c}\text { Фармацевти- } \\
\text { ческая про- } \\
\text { мышленность }\end{array}$ & $\begin{array}{c}114773 \\
459\end{array}$ & 357134 & 36527283 & 39386227 & 11507745 & 14367654 & 48244391 & 65319820 \\
\hline $\begin{array}{c}\text { Медицинская } \\
\text { промышлен- } \\
\text { ность }\end{array}$ & 30302481 & 130423 & 8499569 & 17128361 & 1175084 & 915080 & 8733022 & 17572026 \\
\hline $\begin{array}{c}\text { Легкая про- } \\
\text { мышленность }\end{array}$ & 90545749 & 64396 & 24023331 & 21785880 & 29617527 & 18898563 & 18729864 & 72671062 \\
\hline $\begin{array}{c}\text { Химическая } \\
\text { промышлен- } \\
\text { ность. }\end{array}$ & $\begin{array}{c}460480 \\
803\end{array}$ & 845215 & 75810849 & 79812005 & 93942263 & $\begin{array}{c}129639 \\
722\end{array}$ & $\begin{array}{c}162502 \\
613\end{array}$ & $\begin{array}{c}318206 \\
489\end{array}$ \\
\hline Металлургия & $\begin{array}{c}547420 \\
927\end{array}$ & 178788 & $\begin{array}{c}108547 \\
881\end{array}$ & $\begin{array}{c}102906 \\
479\end{array}$ & $\begin{array}{c}140753 \\
520\end{array}$ & 70648173 & $\begin{array}{c}215517 \\
902\end{array}$ & $\begin{array}{c}301804 \\
241\end{array}$ \\
\hline $\begin{array}{c}\text { Транспортное } \\
\text { машиностро- } \\
\text { ение }\end{array}$ & $\begin{array}{c}257615 \\
083\end{array}$ & 521937 & 63164737 & 69819624 & 54149661 & 45780027 & 71205788 & $\begin{array}{c}226477 \\
322\end{array}$ \\
\hline $\begin{array}{c}\text { Народные ху- } \\
\text { дожественные } \\
\text { промыслы }\end{array}$ & 1050143 & 1278 & 182424 & 277524 & 213286 & 102321 & 448717 & 563702 \\
\hline $\begin{array}{c}\text { Промышлен- } \\
\text { ность воору- } \\
\text { жений }\end{array}$ & $\begin{array}{c}120008 \\
750\end{array}$ & 1126401 & 25259254 & 43972352 & 19998377 & 13913220 & 38096388 & 46100056 \\
\hline $\begin{array}{c}\text { Промышлен- } \\
\text { ность боепри- } \\
\text { пасов }\end{array}$ & 19244178 & 6607 & 2935959 & 3858733 & 524592 & 3898000 & 7298034 & 7872211 \\
\hline $\begin{array}{c}\text { Автомобиль- } \\
\text { ная промыш- } \\
\text { ленность }\end{array}$ & $\begin{array}{c}113452 \\
299\end{array}$ & 65688 & 26538553 & 28802602 & 28994621 & 17863821 & 34330110 & $\begin{array}{c}111573 \\
355\end{array}$ \\
\hline $\begin{array}{c}\text { Радио- } \\
\text { электронная } \\
\text { промышлен- } \\
\text { ность } \\
\end{array}$ & $\begin{array}{c}626518 \\
047\end{array}$ & 1252603 & $\begin{array}{c}185674 \\
026\end{array}$ & $\begin{array}{c}249557 \\
989\end{array}$ & $\begin{array}{c}105105 \\
233\end{array}$ & 32846158 & $\begin{array}{c}216562 \\
657\end{array}$ & $\begin{array}{c}189795 \\
881\end{array}$ \\
\hline Судостроение & $\begin{array}{c}782582 \\
610\end{array}$ & 7518721 & $\begin{array}{c}279709 \\
572\end{array}$ & $\begin{array}{c}216884 \\
439\end{array}$ & $\begin{array}{c}183585 \\
545\end{array}$ & 48959252 & 80304119 & $\begin{array}{c}204100 \\
602\end{array}$ \\
\hline Авиастроение & $\begin{array}{c}1515515 \\
447\end{array}$ & 14856523 & $\begin{array}{c}494405 \\
333\end{array}$ & $\begin{array}{c}356824 \\
308\end{array}$ & $\begin{array}{c}377669 \\
459\end{array}$ & $\begin{array}{c}252099 \\
092\end{array}$ & $\begin{array}{c}438348 \\
920\end{array}$ & $\begin{array}{c}466675 \\
530\end{array}$ \\
\hline $\begin{array}{l}\text { Индустрия } \\
\text { детских } \\
\text { товаров }\end{array}$ & 2013668 & 556 & 635165 & 269216 & 294939 & 551120 & 803990 & 1593301 \\
\hline
\end{tabular}


И. Рыкова и соавторы | I. Rykova et al.51-69

\begin{tabular}{|c|c|c|c|c|c|c|c|c|}
\hline $\begin{array}{c}\text { Промышлен- } \\
\text { ность строй- } \\
\text { материалов }\end{array}$ & $\begin{array}{c}209228 \\
274\end{array}$ & 336359 & 30943906 & 23201384 & 73290115 & 31972287 & 72146969 & 77429790 \\
\hline
\end{tabular}

Оценим влияние активов на себестоимость с помощью инструмента анализа данных «регрессия» ППП Excel (табл. 13).

Таблиия 13

Регрессионый анализ влияния активов на себестоимость организаций, функционирующих в отраслях промышленности России

\begin{tabular}{|c|c|c|c|c|c|c|}
\hline \multicolumn{7}{|c|}{ Регрессионная статистика } \\
\hline $\begin{array}{c}\text { Множествен- } \\
\text { ный R } \\
\end{array}$ & 0,897113083 & & & & & \\
\hline $\mathrm{R}^{2}$ & 0,804811883 & & & & & \\
\hline $\begin{array}{c}\text { Нормирован- } \\
\text { ный R-квадрат }\end{array}$ & 0,795517211 & & & & & \\
\hline $\begin{array}{c}\text { Стандартная } \\
\text { ошибка }\end{array}$ & 54913534353 & & & & & \\
\hline Наблюдения & 23 & & & & & \\
\hline \multicolumn{7}{|c|}{ Дисперсионный анализ } \\
\hline & Df & SS & MS & $\mathrm{F}$ & Значимость F & \\
\hline Регрессия & 1 & $2,61107 \mathrm{E}+23$ & $2,61107 \mathrm{E}+23$ & 86,58 & 6,73133E-09 & \\
\hline Остаток & 21 & $6,33254 \mathrm{E}+22$ & $3,0155 \mathrm{E}+21$ & & & \\
\hline \multirow[t]{2}{*}{ Итого } & 22 & $3,24433 \mathrm{E}+23$ & & & & \\
\hline & Коэффициенты & $\begin{array}{c}\text { Стандартная } \\
\text { ошибка }\end{array}$ & t-статистика & Р-Значение & Нижние 95\% & Верхние 95,0\% \\
\hline Y-пересечение & 37336247276 & 14054462923 & 2,6565 & 0,0147 & 8108391709 & 66564102844 \\
\hline Активы & 0,310625557 & 0,033381591 & 9,3052 & $6,73 \mathrm{E}-09$ & 0,241204738 & 0,380046376 \\
\hline
\end{tabular}

Зависимость описывается следующим уравнением регрессии:

$Y=37336247672+0, \mathbf{3} \cdot X+\varepsilon$,

где $Y$ - себестоимость, $X$ - активы.

Полученная модель статистически значима по критерию Фишера $\left(F_{\text {расч. }}=86,58>F_{\text {крит. }}=4,28\right)$. В соответствии с $t$-критерием Стьюдента $\left(t_{\text {рас. }}=9,31>t_{\text {крит. }}=2,07\right)$ параметр регрессии статистически значим. Модель пригодна для анализа и прогноза.

Регрессионная статистика позволяет по коэффициенту детерминации $\left(R^{2}\right)$ сделать вывод о том, что в $80,4 \%$ отраслей изменение активов приводит к изменению себестоимости. Или, другими словами, 80,4\% вариации себестоимости происходит под воздействием вариации активов, а 19,6\% - под воздействием других, не учтенных в модели факторов. Между себестоимостью и активами имеется прямая линейная зависимость. Параметр регрессии показывает, что при изменении активов на 1 рубль себестоимость меняется на 0,31 рубля.

Для сравнения влияния всех параметров составим сводную таблицу 14.

Таблицуа 14

Параметры регрессии, полученные при формировании оценочной модели

\begin{tabular}{|c|c|c|c|c|}
\hline Показатели & Параметр регрессии & $\boldsymbol{R}^{\mathbf{2}}$ & $\boldsymbol{F}_{\text {pacu. }}$ & $\boldsymbol{T}_{\text {расч. }}$ \\
\hline Активы & 0,31 & 0,848 & 86,58 & 9,31 \\
\hline НА & 25,23 & 0,475 & 18,98 & 4,36 \\
\hline
\end{tabular}


И. Рыкова и соавторы | I. Rykova et al.51-69

\begin{tabular}{|c|c|c|c|c|}
\hline ДЗ & 0,87 & 0,671 & 42,87 & 6,55 \\
\hline КЗ & 1,10 & 0,670 & 42,61 & 6,52 \\
\hline ЗК & 1,24 & 0,772 & 71,19 & 8,44 \\
\hline ЗД & 1,99 & 0,822 & 96,95 & 9,84 \\
\hline К & 1,07 & 0,820 & 95,59 & 9,74 \\
\hline
\end{tabular}

В рамках представленной модели наиболее обоснованной является зависимость себестоимости от размера активов исследуемых организаций, так как $R^{2}$ обладает достаточной величиной для признания адекватности соответствия экономико-математической модели статистическому процессу.

В этой связи при прогнозировании финансовых результатов промышленных организаций России особое внимание должно уделяться факторному анализу себестоимости и ее перспективному изменению под влиянием активов.

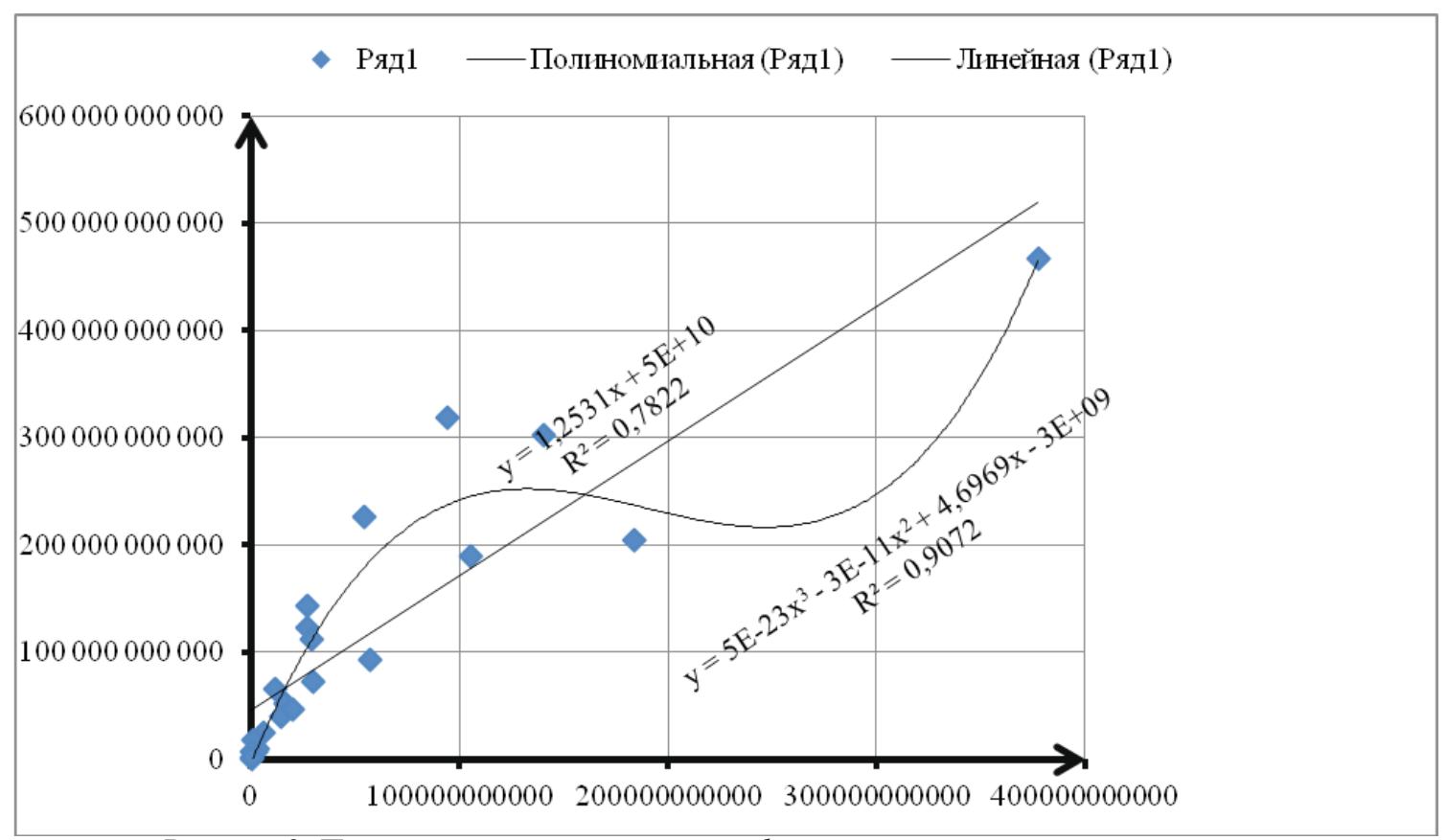

Рисунок 2. Полиномиальная зависимость финансовых результатов от активов

Таким образом, корреляционные связи себестоимости с экономическими факторами оказались хорошими, но модель влияния активов на себестоимость получилась точнее. Поэтому ее можно считать оптимальной в рамках исследования.

\section{Заключение}

Активы, как известно, включают в себя основные средства, нематериальные активы, оборотные средства и иные, предусмотренные законодательством Российской Федерации виды имущества. Выбор состава данных активов, формирование их удельного веса в структуре валюты бухгалтерского баланса в немалой степени положительно будут воздействовать, как на достижение целевого размера чистой прибыли промышленных организаций, так и на привлечение требуемого объема финансирования в качестве средств государственной поддержки.

Оценив влияние стоимостных факторов на себестоимость исследуемой группы предприятий, можно полагать, что качество прибыли в составе финансовых результатов их деятельности может быть значительно лучше в случае соблюдения принципа зависимости затрат от активов. Поэтому прогнозирование затрат, входящих в состав себестоимости промышленных организаций России (материальных расходов, оплаты труда с отчислениями на социальные нужды, амортизации, прочие расходы) с использованием предложенной корреляционной зависимости будет способствовать максимизации корпоративной прибыли, а следовательно, увеличению налоговых поступлений в казну государства.

Таким образом, в условиях возникших диспропорций в структуре валовой добавленной стоимости по отраслям российской экономики, дефицита бюджетных ресурсов, необходимых для 
обеспечения качественной господдержки промышленности, низкой рентабельности и даже убыточности ряда организаций реального сектора экономики крайне важно повысить качество прибыли, инвестируемой в развитие производства.

Для ликвидации указанных диспропорций целесообразно на уровне организаций использовать предложенную в работе экономико-математическую зависимость себестоимости промышленных товаров от активов хозяйствующих субъектов, сгруппированных по признаку отраслевой принадлежности и подчиненности Министерству промышленности и торговли Российской Федерации. При этом на уровне государственного управления следует предусмотреть в Стратегии социально-экономического развития Российской Федерации на период до 2030 года комплекс мер по оптимизации финансовых результатов, механизмы и пути реализации оптимистического сценария функционирования реального сектора.

\section{Список литературы}

1. Бреннер Р. Экономика глобальной турбулентности: развитые капиталистические экономики в период от долгого бума до долгого спада, 1945-2005 / пер. с англ. А. Гусева, Р. Хаиткулова; под науч. ред. И. Чубарова. Нац. исслед. ун-т «Высшая школа экономики». М.: Изд. дом Высшей школы экономики. 2014. - 552 с.

2. Дасковский В., Киселев В. Нисходящая траектория экономики: причины и последствия // Экономист. 2016. № 3, т. 31. С. 12-13.

3. Дмитриевский А.Н., Комков Н.И., Кротова М.В., Романцов В.С. Стратегические альтернативы импортозамещения оборудования ТЭК для нефтегазового комплекса // Проблемы прогнозирования. 2016. № 1, т. 25. С. 33-34.

4. Егоршин А.П. Кризис и управление предприятием. Н. Новгород: НИМБ, 2011. - 416 с.

5. Ивашковская И.В. Моделирование стоимости компании. Стратегическая ответственность совета директоров. М.: ИНФРА-М. 2013. - 430 с.

6. Идрисов Г. Промышленная трансформация при ухудшении условий торговли // Экономическое развитие России. 2016. № 3, т. 7. С. 42-43.

7. Романова Л.Е. Экономический анализ. Учебное пособие. СПб: Питер. 2011. - 336 с.

8. Министерство промышленности и торговли Российской Федерации: официальный сайт [Электронный ресурc]. URL: http://minpromtorg.gov.ru/open_ministry/declaration/ main (дата обращения: 23.01.2016 г.).

9. Министерство промышленности и торговли РФ: официальный сайт [Электронный pecypc]. URL: http://minpromtorg.gov.ru/open_ministry/declaration/import (дата обращения: 23.01.2016 г,).

10. Постановление Правительства Российской Федерации от 15 апреля 2014 г. № 328 «Об утверждении государственной программы Российской Федерации «Развитие промышленности и повышение ее конкурентоспособности» // Россия в цифрах. 2015: Крат. стат. сб. / Росстат. М., 2015. - 545 с.

11. Ромер Д. Высшая макроэкономика. Учебник / пер. с англ. под науч. ред. В.М. Полтеровича // Издательский дом Высшей школы экономики, 2014. - 855 с.

12. Стратегия развития легкой промышленности в Российской Федерации на период до 2025 года / Министерство промышленности и торговли Российской Федерации. М., 2015. -38 c.

13. Федеральная служба государственной статистики: официальный сайт [Электронный pecypc]. URL: http://www.gks.ru/free_doc/new_site/vvp/130116/tab10a.htm (дата обращения: 23.01.2016 г.).

14. Calcagno P., Benefield J.D. (2013) Economic freedom, the cost of public borrowing, and state bond ratings. Journal of Financial Economic Policy, vol. 5, no. 1, pp. 72-85. 


\title{
INFLUENCE FACTORS ON THE FINANCIAL PERFORMANCE OF INDUSTRIAL ORGANIZATIONS RUSSIA WITH REGARD TO THE STATE SUPPORT OF INDUSTRY ECONOMY
}

\section{Inna Rykova,}

Doctor of Economics The Academy of natural Sciences Head of the Sectorial Economy Center Federal state budgetary institution «Scientific research Institute of Finance», Federal state budgetary institution «Scientific research Institute of Finance» Ministry of finance of the Russian Federation. Address: 127006, Moscow, Nastasyinsky Lane, 3, p. 2.

\section{Denis Korablev,}

Candidate of economic Sciences, researcher of the Sectorial Economy Center Federal state budgetary institution "Scientific research Institute of Finance», Federal state budgetary institution "Scientific research Institute of Finance» Ministry of finance of the Russian

Federation. Address: 127006, Moscow, Nastasyinsky Lane, 3, p. 2.

\section{Roman Gubanov,}

Candidate of economic Sciences, senior researcher of the Sectorial Economy Center Federal state budgetary institution «Scientific research Institute of Finance», Federal state budgetary institution "Scientific research Institute of Finance» Ministry of finance of the Russian Federation. Address: 127006, Moscow, Nastasyinsky Lane, 3, p. 2.

\begin{abstract}
This article presents the results of empirical research of influence of parameters of functioning of activity of the organizations of the real sector of the economy on their financial results based on the experience of state support of industries of Russia and developing countries. On the basis of correlation analysis of data on volumes of shipment of products, goods, works and services of domestic enterprises, formed for the period from 2008 to 2015, were revealed peculiarities of changes in the economic performance of enterprises by type of activity.

The determination of the degree of influence of factors on revenue, cost and corporate profit is one of the most challenging tasks in the management of financial results. It is possible to allocate a number of the most significant factors which will allow to solve this problem: the size of the short-term and long-term loans and credits, the amount of capital and reserves, accounts receivable organizations, the cost of products, the value of the assets.

The relevance of this study lies in the fact that in the process of formation of financial results of the real sector of the economy, it is necessary to study not only the impact of equity capital and borrowed funds from external sources of funding, but the features of state support of selected industries: mechanical engineering, automotive engineering, aviation industry, metallurgy, timber industry, textile industry.

The purpose of this article is to determine the factors that influence the cost, revenue, profit and other financial outcomes of organizations of Russian industry taking into account the efficiency of state support of the leading sectors of the economy.
\end{abstract}

Keywords: organization, financial support, financial results, loan capital, capital and reserves, the model correlation of cost, volume of sales

JEL: G21

\section{References}

1. Brenner R. (2014) Jekonomika global'noj turbulentnosti: razvitye kapitalisticheskie jekonomiki v period ot dolgogo buma do dolgogo spada, 1945-2005 [Economics of global turbulence: the advanced capitalist economies in the period from long boom to long downturn, 1945-2005 per. from English. A. Guseva, R. Aitkulov; under scientific. edited by Igor 
Chubarov; NAT. issled. University "Higher school of Economics"]. Moscow: Publishing House. the house of the Higher school of Economics (in Russian).

2. Calcagno P., Benefield J.D. (2013) Economic freedom, the cost of public borrowing, and state bond ratings. Journal of Financial Economic Policy, vol. 5, no. 1, pp. 72-85.

3. Daskovskij V., Kiselev V. (2016) Nishodjashhaja traektorija jekonomiki: prichiny i posledstvija [The Downward trajectory of the economy: causes and consequences] The Economist, vol. 31, no 3, pp. 12-13.

4. Dmitrievskij A.N., Komkov N.I., Krotova M.V., Romancov V.S. (2016) Strategicheskie al'ternativy importozameshhenija oborudovanija TJeK dlja neftegazovogo kompleksa [Strategic options of import substitution of equipment of TEK for oil and gas industry]. Problems offorecasting, vol. 25, no 1, pp. 33-34.

5. Egorshin A.P. (2011) Krizis i upravlenie predprijatiem [Crisis and Crisis management]. N. Novgorod: NIMB (in Russian).

6. Ivashkovskaja I.V. (2013) Modelirovanie stoimosti kompanii. Strategicheskaja otvetstvennost'soveta direktorov [Modeling value of the company. Strategic responsibility of the Board of Directors]. Moscow: INFRA-M (in Russian).

7. Idrisov G. (2016) Promyshlennaja transformacija pri uhudshenii uslovij torgovli [Industrial transformation with the deterioration of terms of trade]. Economic development of Russia, vol. 7, no 3, pp. 42-43.

8. Ministerstvo promyshlennosti i torgovli Rossijskoj Federacii (2016): oficial'nyj sajt [Jelektronnyj resurs]. Availabl at: http://minpromtorg.gov.ru/open_ministry/declaration/main (accessed: 23 2016).

9. Ministerstvo promyshlennosti i torgovli RF (2016): oficial'nyj sajt [Jelektronnyj resurs]. Availabl at: http://minpromtorg.gov.ru/open_ministry/declaration/import (accessed: 23 January 2016).

10. Postanovlenie Pravitel’stva Rossijskoj Federacii (2014) ot 15 aprelja 2014 g. № 328 «Ob utverzhdenii gosudarstvennoj programmy Rossijskoj Federacii "Razvitie promyshlennosti i povyshenie ee konkurentosposobnosti" [Russian Federation Government Resolution of 15 April 2014 № 328 «The state program "Developing industry and increasing its competitiveness"]. Rossija v cifrah (2015). Krat. stat. sb. [2015: the Times. stat. SB.] Moscow: Rosstat (in Russian).

11. Romanova L.E. (2011) Jekonomicheskij analiz [Economic analysis]. Saint Petersburg: Piter (in Russian).

12. Romer D. (2014) Vysshaja makrojekonomikaUchebnik [Graduate macroeconomics. Textbook] / per. sangl. pod nauch. red. V.M. Polterovicha / Publishing house of the Higher school of Economics.

13. Strategija razvitija legkoj promyshlennosti v Rossijskoj Federacii na period do 2025 goda (2015). Ministerstvo promyshlennosti i torgovli Rossijskoj Federacii [The strategy of light industry development in the Russian Federation for the period till 2025. Ministry of industry and trade of the Russian Federation]. Moscow (in Russian). 